\title{
27. TWO LAMELLAPTYCHI (AMMONOIDEA) FROM THE MAGELLAN RISE IN THE CENTRAL PACIFIC
}

\author{
Otto Renz, Museum of Natural History, Basel, Switzerland
}

\section{INTRODUCTION}

A piece of limestone with a fossil recovered from Core 94, Site 167, located on the Magellan Rise in the Central Pacific was sent by Dr.Y. Lancelot to the Museum of Natural History in Basel. A sedimentary column of 1168 meters was penetrated at Site 167 and the sample with the fossil derives from $20 \mathrm{~cm}$ above the basalt basement.

\section{LITHOLOGY}

The core consists of a light green-gray limestone. Layers especially rich in Radiolaria alternate with zones of more calcareous, darker colored material, containing fewer Radiolaria. In the vicinity of the fossil the rock is composed of $64 \%$ carbonate, $22 \%$ Radiolaria with a few silicified foraminifera and small spines of echinoids (Plate 1, Figure 3). The green-gray clay amounts to $14 \%$. The more calcareous bands are formed of $80 \%$ carbonate, $12.6 \%$ clay, and only $7.4 \%$ Radiolaria and undifferentiated silica.

The foraminiferal content consists, according to Dr. J. P. Beckmann of the Swiss Federal Institute of Technology, Zurich, of the following species: Lenticulina sp., Vaginulinopsis ? sp., Lingulina nodosaria Reuss, Dentalina sp. (? ancestor of $D$. cylindroides Reuss). An accurate age determination is not possible based on such a poor fauna. Dr. Beckmann mentions that the Nodosariidae are generally indicative of outer shelf and bathyal environments.

The nannoflora in the vicinity of the fossil (Plate 1, Figure 4) was studied by Dr. Hans R. Thierstein. The following association of nannofossils was determined: Watznaueria britannica (Stradner), Watznaueria barnesae (Black), Cyclagelosphaera margareli. Noel, Parhabdolithus embergeri (Noel), Lithraphidites caniolensis Deflandre, Diazomatholithus lehmani Noel, Cruciellipsis chiasta (Worsley), Nannoconus sp., and Cruciellipsis cf. cuvillieri (Manivit). The age of this assemblage ranges from Upper Tithonian to Lower Berriasian.

Conspicuous are different types of quartz veinlets. Some are tabular, generally crossing the core vertical to the bedding; others seem to branch out from a center in all directions. The color of these veins is predominantly light gray but may change locally toward brownish and opaque milky shades. At one place a tabular quartz vein has been broken into several fragments which then were thrust upon each other. This might indicate an early formation of these veinlets at a time when the sediment was not yet well consolidated.

\section{PREPARATION AND STATE OF PRESERVATION}

When the core was split along its longitudinal axis a small shell was cut and the corresponding cross sections appeared on both halves. The shell displays the same gray color as the quartz veinlets nearby. It is entirely silicified, but nevertheless porous. Its internal structure has been mostly destroyed, probably during silification.

The two fragments were cut from the respective cores and cleaned of sediment with fine needles and brushes. Finally the fossil was washed with a weak solution of HC1. This fossil is an aptychus, displaying a lamina pattern, characteristic for the group of Lamellaptychus Trauth, 1927. It might best be compared with Lamellaptychus rectecostatus (Peters). The valve has been cut obliquely by the sawblade which track, according to the information of Dr. Lancelot, amounts to $1.5 \mathrm{~mm}$ (see reconstruction, Plate 1, Figure 1).

The ventral half of the valve is satisfactorily preserved. From the larger dorsal half, however, the apex and the major part of the dorsal region are missing. Moreover, the dorsal half of the lateral margin broke off, probably during deposition, so that it lies at a right angle to the remaining fragment. Nevertheless, the reconstruction of the three fragments (Plate 1, Figure 2) can be considered reliable.

\section{PALEOZOOLOGICAL DESCRIPTION}

A condensed historical review and data concerning the terminology of the aptychus valve are given in a study on the aptychi from Leg 11, Site 105, in the western Atlantic (Renz, 1972).

Lamellaptychus cf. rectecostatus (Peters) (Plate 1, Figures 1,2)

1849 Aptychus von Roveredo, Quenstedt, pl. 22, fig. 26 a, b, p. 315 .

1854 Aptychus rectecostatus Peters, p. 442.

1863 Aptychus of Ammonites bous Oppel, pl. 70, fig. 1, p.253.

1863 Aptychus of Ammonites euglyptus Oppel, only pl.71, fig. 4, p. 254.

1870 Aptychus of Oppelia steraspis Oppel (= Neochetoceras steraspis (Oppel), Waagen, pl. 40, fig. 4, p. 210.

1886 Aptychus Beyrichi Sokoloff, pl. 3, fig. 4, p. 25.

1887-1888 Aptychus of Ammonites lingulatus solenoides Quenstedt, pl. 126, fig. 8, p. 1092.

1936 ?Lamellaptychus rectecostatus (Peters), Trauth, p. 69-70.

1938 Lamellaptychus rectecostatus (Peters), Trauth, pl. 10 , fig. 1-3, p. 131, footnote 29 (cum syn.).

1942 Lamellaptychus rectecostatus (Peters), Imlay, p. 1458.

1962 Lamellaptychus rectecostatus (Peters), Gasiorowski, pl. 3-6. 
1970 Lamellaptychus recteocostatus (Peters), DurandDelga and Gasiorowski, p. 768-769.

1970 Lamellaptychus rectecostatus (Peters), Cuzzi, p. 44

Holotype: Quenstedt, 1849, pl. 22, fig. 26a, b, p. 315.

Locus typicus: Tithonian (Diphia Limestone), Rovereto, Southern Alps.

It is a left valve which laid with its concave side turned upwards. After reconstruction of the three available fragments, the measurements are width index 0.62 against 0.51 for the holotype. The limits vary, according to Trauth (1938, p. 132), between 0.40 and 0.60 .

No indication of a lateral depression can be observed on the convex side. The laminae are characterized by their straightness, also along the symphysal margin, where they end in acute angles against the symphysal edge without any indication of an inflection. They terminate against the ventral edge of the valve and the inner laminae converge slightly against the terminal point. Along the bottoms of the furrows no sculpture can be detected. According to Trauth, 1938 (p. 131-132), the laminae might be slightly flexuous in the early stages, up to a width of $8 \mathrm{~mm}$. Such forms are, however, still referred to $\mathrm{L}$. rectecostatus and not to L. beyrichi (Oppel).

On the ends of the two fragments, which point towards the apex, a layer is coating the surface leaving only narrow splits and elongated to rounded pores open. Such a layer has not been observed on the surface of L. rectecostatus, but it is characteristic for Punctaptychus. It probably corresponds to the "Decklage" of Trauth, 1935 (p. 312, pl. 12, fig. 5, 6). This layer, restricted to the juvenile stage, represents the main feature separating the present specimen from the holotype of $\mathrm{L}$. rectecostatus.

About the connection of $\mathrm{L}$. rectecostatus to respective ammonites little is known. Oppel (1863) assumed a relation to the Oppeliidae. Quenstedt (1887-88) mentions a $\mathbf{L}$. rectecostatus together with Haploceras lingulatum (Quenstedt) (see also Trauth, 1938, p. 133).

L. rectecostatus occurs especially frequently in the Kimmeridgian and Tithonian of the Mediterranean region. Occasionally it has been reported from early Lower Cretaceous (Trauth, 1938, p. 133, Durand-Delga and Gasiorowski, 1970, p. 768-769). From Cuba (Province Pinar del Rio) Trauth (1936) mentions a questionable L. rectecostatus together with $\mathrm{L}$. seranonis (Coquand) and $\mathrm{L}$. angulocostatus (Peters). None of the specimens examined by Imlay (1942) from this region, however, are comparable with $\mathrm{L}$. rectecostatus.

An Upper Jurassic (Tithonian) age is most probable for the present aptychus. Evidently a somewhat younger age (Berriasian) is not to be excluded. This agrees with the age determination based on the nannoflora.

Trauth (1938, p. 132) draws attention to the difficulty of separating Lamellaptychus from Punctaptychus, especially when the cover layer has been removed by weathering. The only feature separating the two groups consists thus in the absence or presence of this cover layer. In this respect some observations on Punctaptychus rectecostatus Cuzzi, 1952, are necessary.

\section{Punctaptychus rectecostatus Cuzzi}

1880 Aptychus punctatus Favre, pl. 3, fig. 14, p. 42.

1935 Punctaptychus punctatus Trauth, pl. 12, fig. 3, p. 315.

1962 Punctaptychus rectecostatus Cuzzi, pl. 17, fig. 4-6, p. 46.

1970 Punctaptychus rectecostatus Cuzzi, Barbera Lamagna, pl. 5, fig. 1, 9, 11; pl. 6, fig. 4, p. 234.

Holotype: Cuzzi, 1962, pl. 17, fig. 5, p. 46.

Locus typicus: Provincia Varese, Majolica inferiore (Kimmeridgian-Tithonian).

Cuzzi introduced the new name for forms with an identical lamina pattern as found in L. rectecostatus. The difference between the two forms is therefore restricted to the cover layer which overlaps the entire surface of Punctaptychus rectecostatus.

Our present form from the Magellan Rise could therefore be interpreted as intermediate between Lamellaptychus rectecostatus and Punctaptychus rectecostatus. Both forms have their major development in the Upper Jurassic.

\section{A SECOND LAMELLAPTYCHUS FROM LEG 17, SITE 167}

Another sample containing poorly preserved remains of a Lamellaptychus was received from Dr. R. Douglas, Department of Geology, Case Western Reserve University, Cleveland, Ohio. The sample has been extracted from Leg 17 , Site 167 , Core 72 , Section $1,78-80 \mathrm{~cm}$, from a depth of about 954 meters below sea floor. The core consists of a whitish, dense, and brittle "Scaglia"-like limestone interbedded with abundant, very thin laminae, consisting of purplish, apparently clayey material, which does not react with $\mathrm{HCl}$.

The Lamellaptychus represents a right valve from which only parts of the ventral half were preserved. When cutting the core the surface of the valve was hit by the sawblade at an angle of about $20^{\circ}$, destroying the major part of the original fragment. An attempted reconstruction is shown on Plate 1 in Figure 5. The most important feature is a retroverse lamina pattern recognizable on the fragment which forms part of the symphysal edge.

The present Lamellaptychus might, therefore, be compared with similar forms found within the Hauterivian section of Leg 11, Site 105, in the western Atlantic. A specific determination of the present fragments can, however, not be given.

\section{LAMELLAPTYCHUS IN THE CIRCUM-PACIFIC UPPER JURASSIC}

The stratigraphy of the Upper Jurassic along the Circum-Pacific borders has been discussed by numerous authors. We may refer to Dacque (1911) and especially to Arkell (1953 and 1956). Aptychi, however, are scarcely mentioned within these extended areas.

The pacific border of the United States has been affected during the Kimmeridgian-Tithonian by the 
Nevadan orogeny (Arkell, 1956, fig. 87, p. 551). After these movements a geosyncline developed in the area of the present Coast Ranges and has been filled by a thick sequence of Tithonian sediments (Knoxville Formation and Franciscan Formation). Numerous ammonite faunas were described, but no reliable occurrences of aptychi are so far known to us from these deposits (Anderson, 1945, pl. 11, fig. 7, 8, p. 985).

In Mexico the Upper Jurassic is characterized by abundant ammonite faunas of great variety studied mainly by Burckhardt (1906, 1912, and 1930). Lamellaptychi are, however, not mentioned from this area. A Laevaptychus has been described by Castillo and Aguilera (1895, pl. 22, fig. 8, p. 45).

In the Andes of Venezuela, Colombia, and Ecuador predominantly red beds with numerous porphyrite intrusions (La Quinta Formation and Giron Formation) were deposited during Upper Jurassic times. Marine Upper Jurassic appears again in the Andes of Argentina (Arkell, 1956, fig. 94, p. 579). The deposits contain rich cephalopod faunas amongst which the Appeliidae and Haploceratidae (H. elimatum (Oppel)) occur frequently. Leanza (1945, p.7) mentions a Punctaptychus punctatus (Voltz) which is, as we have pointed out above, closely related to the Lamellaptychus from the Magellan Rise.

Yet undetermined Lamellaptychi ("aptychi imbricati") and Laevaptychi ("aptychi cellulosi") are reported by Leanza (1945, p. 12) from the Tithonian from the Rio Malargue. Rusconi (1948, fig. 6, p. 14, 20) mentions a questionable Lamellaptychus lamellosus (Parkinson) from the Upper Jurassic of the Mendoza area. Also uncertain is a Lamellaptychus sparsilamellosus (Gümbel) reported by Haupt (1907, p. 202) from Loteno under the name of Aptychus cf. exsculptus Schauroth (see Trauth, 1938, p. 165). From the Mendoza region Steuer (1921, pl. 24, fig. 3, 4) and Krantz (1926, pl. 17, fig. 7, 8, p. 455) also described various Laevaptychi.

During Upper Jurassic times most of Australia formed part of a continent which was bordered to the east by the Papuan Geosyncline (Arkell, 1956, fig. 71, p. 457). Here Upper Jurassic deposits are widely distributed, especially also in New Zealand, but as far as we know a facies containing aptychi has not been reported.

From the Moluccas, in the Indonesian Archipelago, aptychi appear again on the island of Buru, from where a red limestone, resembling the Alpine Tithonian, is reported. Martin (1900, p. 9) mentions a Laevaptychus.

From the Upper Jurassic of the eastern Celebes (Wandel, 1936, with a contribution of Trauth, p. 502) a Lamellaptychus cf. plicatus (Pillet), 1886, has been figured (pl. 16, fig. 7). Later Trauth (1938, pl. 13, fig. 23, p. 192) described this form again. It is deposited in the Museum of Natural History in Basel.

\section{ACKNOWLEDGMENTS}

This note has been prepared at the Museum of Natural History in Basel. We are especially grateful to Dr. Y. Lancelot, who first recognized the fossil here described. Furthermore we want to thank Dr. E. L. Winterer and Dr.
J. I. Ewing, Leg 17 co-chief scientists, for having entrusted us a, so far, unique fossil for study. We also wish to express our thanks to Dr. H. R. Thierstein from the Swiss Federal Institute of Technology in Zurich for the determination of the nannoplankton. Much help has been received from Dr. H. G. Kugler, Mr. R. Panchaud, and Mr. W. Suter, who did the photographic work. The observations with the scanning electron microscope were carried out by Mr. R. Guggenheim from the Institute of Geology, University of Basel.

\section{REFERENCES}

Anderson, F. M., 1945. Knoxville Series in the California Mesozoic. Bull. Geol. Soc. Am. 56 (2), 909.

Arkell, W. J., 1953. Two Jurassic Ammonites from South Island, New Zealand and a note on the Pacific Ocean in the Jurassic. New Zealand J. Sci. Tech. 35, 259.

, 1956. Jurassic Geology of the World. London, $806 \mathrm{p}$.

Barbera, Lamagna C., 1970. Stratigrafia e paleontologia della formazione degli scisti ad aptici dei dintorni di Bolognola (Macerata). 1) Studio sistematico e strutturale degli aptici giurassici. Con un'appendice mineralogica di L. Pingue. Mem. Soc. Natur. Napoli. Suppl. Boll. 78, 215.

Burckhardt, C., 1906. La faune jurassique de Mazapil. Bol. Inst. Geol. México. 23. 180 p. , 1912. Faunes jurassiques et crétacés de San Pedro del Gallo. Bol. Inst. Geol. México. 29. 264 p. 1930. Etude synthétique sur le Mésoqoique mexicaine. Mém. Soc. Palentol. Suisse 49.280 p.

Castillo, A. and Aguilera, J. G., 1895. Fauna fóssil de la Sierra de Catorce, San Luis Potosi. Bol. Com. Geol. México $1.55 \mathrm{p}$.

Cuzzi, G., 1962. Osservazioni sul genere Punctaptychus e sulla spezie Punctaptychus punctatus (Voltz). Boll. Soc. Paleontol. Ital. 1/2, 43.

Dacqué, E., 1911. Die Stratigraphie des marinen Jura an den Rändern des Pazifischen Oceans. Geol. Rundschau. 2,464 .

Durand-Delga, M. and Gasiorowski, S. M., 1970. Les niveaux à Aptychus dans les pays autour de la Méditerranée occidentale et dans les Carpathes. C. R. Acad. Sci. Paris. 270, 767.

Favre, E., 1880. Description des fossiles des couches tithoniques des Alpes Fribourgeoises. Mém. Soc. Paleontol. Suisse. 674 p.

Gasiorowski, S. M., 1962. Aptychi from the Dogger, Malm and Neocomian in the Western Carpathians and their stratigraphical value. Studia Geol. Polonica. 10. $134 \mathrm{p}$.

Haupt, O., 1907. Beiträge zur Fauna des oberen Malm und unteren Kreide in der argentinischen Cordillere. Jahrb. Min., Geol. Beil.-Bd. 23, 187.

Imlay, R. W., 1942. Late Jurassic fossils from Cuba and their economic significance. Bull. Geol. Soc. Am. 53, 1417.

Krantz, F., 1926. Die Ammoniten des Mittel- und Obertithons (Province of Mendoza, Argentina). Geol. Rundschau. 17 a, 428.

Leanza, A. F., 1945. Ammonites del Jurasico superior y del Cretáceo inferior de la Sierra Azul, en la parte meridional de la provincia de Mendoza. Ann. Mus. de la Plata, N.S., Sec. A, no. 1.99 p.

Martin, K., 1900. Aptychenkalk von Buru. Z. Deut. Geol. Gessell., Verh. 52, 9. 
Oppel, A., 1863. Über jurassische Cephalopoden. Palaeontol. Mitt. Mus. bayer. Staates 3, 163.

Peters, K., 1854. Die Aptychen der österreichischen Neocomien-und obere Juraschichten. Jahrb. Geol. Reichsanstalt Wien. 5, 439.

Quenstedt, F. A., 1849. Petrefactenkunde Deutschlands. Die Cephalopoden. Tübingen. 580 p.

1887-1888. Die Ammoniten des schwäbischen Jura 3. Der Weisse Jura. Stuttgart. 817.

Renz, O., 1972. Aptychi (Ammonoidea) from the Upper Jurassic and Lower Cretaceous of the western North Atlantic. (Site 105, Leg 11, DSDP. In Hollister, C. D., Ewing, J. I., et al., 1972. Initial Reports of the Deep Sea Drilling Project, Volume XI. Washington (U. S. Government Printing Office). 607.

Rusconi, C., 1948. Los ápticos del Jurásico de Mendoza. Publ. Univ. Nac. Tucumán. 456, 7.
Sokoloff, W., 1886. Couches tithoniques de la Crimée. Mat. z. Geol. Russlands. 13. St. Petersburg.

Steuer, A., 1921. Estratos jurásicos argentinos. Actas Acad. Nac. de Ciencias, Cordoba. 7, 108.

Trauth, F., 1935. Die Punctaptychi des Oberjura und der Unterkreide. Jahrb. Geol. Bundesanst. Wien. 85, 309. , 1936. Über Aptychenfunde auf Cuba. Koninkl. Ned. Akad. Wetenschap. Proc. Sect. Sci. 39 (1), 66. 1938. Die Lamellaptychi des Oberjura und der Unterkreide. Palaeontographica, Abt. A. 88, 115.

Waagen, W., 1870. Über die Ansatzstelle der Haftmuskeln beim Nautilus und der Ammonoideen. Palaeontographica. 17, 185.

Wandel, G., 1936. Beiträge zur Kenntnis der jurassischen Molluskenfauna von Misol, Ost-Celebes, Buton, Seran und Jamdena (mit einem Beitrag von Prof. F. Trauth). Neues. Jahrb. Min., Geol. Beil.-Bd. 75, Abt. B, 447. 



\section{PLATE 1}

Figure 1 Lamellaptychus cf. rectecostatus (Peters), left valve, reconstruction. $6 \mathrm{X}$.

Figure 2 The three available fragments in their correct position. 6 X.

Figure 3 Surface of the sediment in the vicinity of L. cf. rectecostatus. Predominant are Radiolaria. All fossils are silicified in a calcareous groundmass. $15 \mathrm{X}$.

Figure 4 Nannoplankton in the vicinity of L. cf. rectecostatus. $15^{\prime} 500 \mathrm{X}$.

Figure 5 Lamellaptychus sp., right valve, reconstruction (167-72-1, 78-80 cm). 3X. 


\section{PLATE 1}
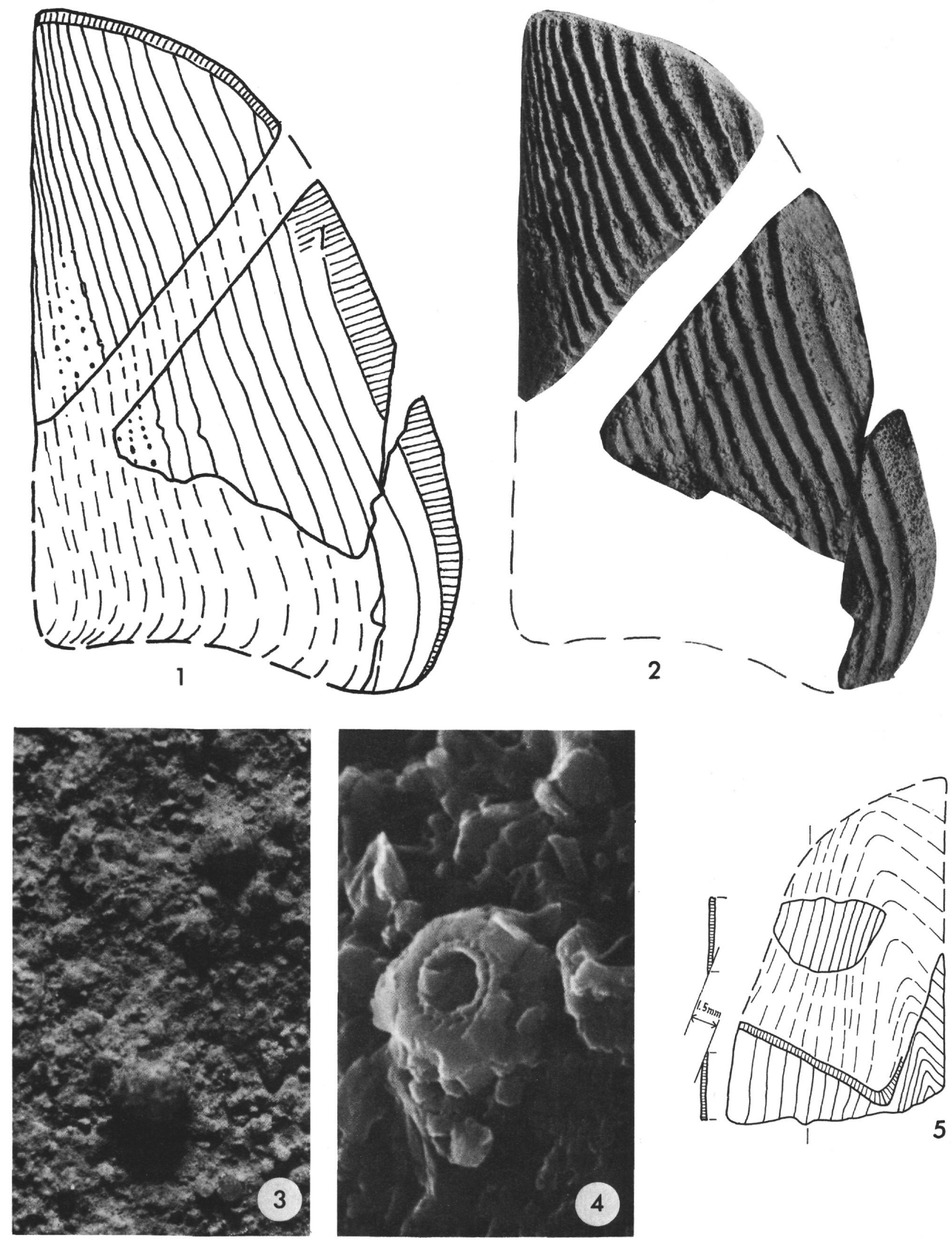